UDC 541.13.544.65

\title{
THE EFFECT OF VARIOUS FACTORS ON THE COMPOSITION OF ELECTROLYTIC THIN FILMS Sb-Se
}

\author{
V.A. Majidzade \\ Institute of Catalysis and Inorganic Chemistry named after Acad.M.Nagiyev \\ H.Javid ave., 113, Baku AZ 1143, Azerbaijan Republic; e-mail: vuska80@mail.ru
}

Received 30.06.2018

\begin{abstract}
The effect to various factors such as temperature, concentration of components in the electrolyte, current density on the composition of thin electrodeposited semiconductive Sb-Se films were viewed in the work. Results obtained indicate that the stibium content in the deposited compounds increases as temperature and concentration of $\mathrm{SbOCl}$ rise. As the current density, $\mathrm{H}_{2} \mathrm{SeO} \mathrm{O}_{3}$ and $\mathrm{C}_{4} \mathrm{H}_{6} \mathrm{O}_{6}$ concentration rises, the stibium content in the films obtained goes dpwn respectively. It revealed that black, uniform, crystalline and lustrous coatings of $\mathrm{Sb}_{2} \mathrm{Se}_{3}$ compound are generated in temperature interval 298-318K, current density 20-60 $\mathrm{MA} / \mathrm{cm}^{2}$ out of electrolyte 0,01-0,09 $\mathrm{M} \mathrm{SbOCl,0,01-0,09}$ $\mathrm{MH}_{2} \mathrm{SeO}_{3}$, and compounds of 0.001-0.007 M tartaric acid.
\end{abstract}

Keywords: electrodeposition, $\mathrm{Sb}$-Se thin films, current density, semiconductors

\section{İNTRODUCTION}

Recently, the interest has been growing in thin film materials [1-5]. Note that thin films with varied physicochemical properties are applied widely in the capacity of various functional coatings for increasing stability, corrosion resistance, improving magnetic and electrical properties. The application of the thin film materials in aeronautics and space technology, mechanical engineering, medicine, solar energetic, accumulation of energy; as supercapacitors, digital microelectronics, etc. helps to decrease the bulk of materials in various devices [6-8]. Along with these, the nano-structural films have attracted much attention because of their unique properties in functional materials.

The $\mathrm{Sb}_{2} \mathrm{Se}_{3}$ films arouse interest from their application in microwave and thermoelectrical chilling devices, optic electronic mechanisms, etc. In this respect, $\mathrm{Sb}_{2} \mathrm{Se}_{3}$ compound is a laminated structural semiconductor with orthorhombic crystalline configuration where each $\mathrm{Sb}$ and $\mathrm{Se}$ atoms are bonded with three opposite atoms which, in turn, are connected through weak subordinate bonds in the crystal [9].

The thin $\mathrm{Sb}_{2} \mathrm{Se}_{3}$ semiconductive films are obtained by different methods, including chemical precipitation from solutions, electrodeposition, jet pyrolysis, vacuum thermal evaporation and so on.

In our work, the thin $\mathrm{Sb}_{2} \mathrm{Se}_{3}$ semiconductive films were synthesized by a chemical method from the tartaric electrolyte. The electroreduction of each initial component was tested individually before the study of SbSe electrodeposition $[10,11]$.

The goal of the work is a study an effect of some factors on the composition and quality of thin semiconductive Sb-Se films. 


\section{EXPERIMENTAL PART}

Experimental procedures based on the use of electrochemical method for production of $\mathrm{Sb}$-Se thin films were carried out as follows.

At first, the tartaric acid was dissolved in bidistilled water for the preparation of electrolytes of initial components. Then $\mathrm{SbOCl}$ (analytical grade) and $\mathrm{H}_{2} \mathrm{SeO}_{3}$ (analytical grade) with required concentration were dissolved in the background solution of the tartaric acid, respectively.

The polarization curves were recorded by IVIUMSTATEl electrochemical Interface potentiometer. The electrochemical triode glass cell was used for this purpose. $\mathrm{A} \mathrm{Pt}$ electrode with an area of $0.02 \mathrm{sm}^{2}$ was utilized as a working electrode. A silver chloride electrode served as a reference electrode, whereas a platinum disk with $4.0 \mathrm{sm}^{2}$ area was an auxiliary electrode. Also, a universal ultra thermostat UTU-4 was used to arrange temperature in the electrolyzer.

The electrochemical deposition processes proceeded through the use of potentiodynamic and galvanostatic methods. In this case, $\mathrm{Ni}$ electrode with an area of $2.0 \mathrm{sm}^{2}$ was used.

The composition of $\mathrm{Sb}$-Se cathodic deposits was determined by using JEOL JSX 3222 Element Analyzer with energy-dispersive X-ray fluorescence spectroscopy (EDXRF) system (JEOL, Japan). It is an analytical technique used for the elemental analysis or chemical characterization of a sample (metals and alloys).

\section{RESULTS AND DISCUSSION}

The potentiodynamic polarization investigations were carried out to determine a potential region where antimony and selenium co-deposited. The obtained results are given in

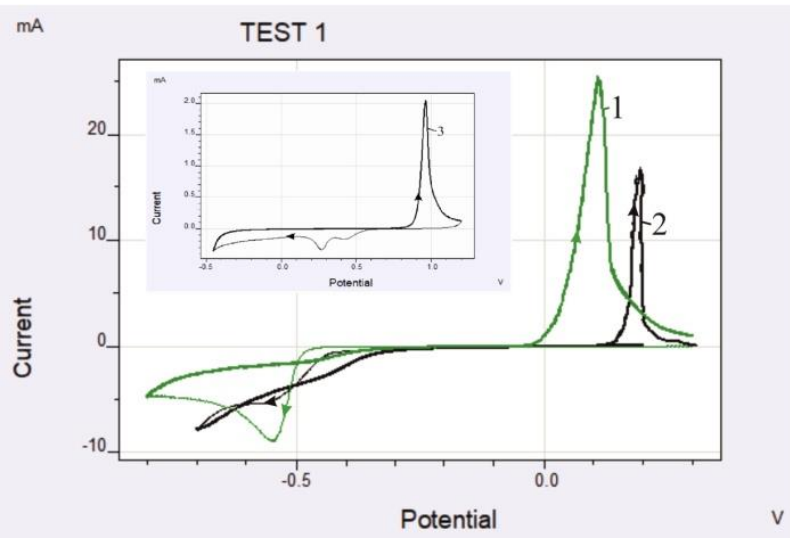

Following the identification of potential region for electrodeposition of $\mathrm{Sb}-\mathrm{Se}$, the effect of some factors on the composition of the films has been studied.

The effect of temperature on the composition of the films has been studied within 298-358 K intervals (fig. 2.).

As it is seen from the figure, the stibium content in the composition of cathodic films increases as the electrolyte temperature rises.
Fig.1 which shows that the simultaneous electrodeposition process of stibium with selenium takes place within $-0.42-(-0.7) \mathrm{V}$.

Fig. 1. The cyclic polarization curves of the electroreduction of stibium, selenium and SbSe. Electrolyte (M):

1- $0.05 \mathrm{SbOCl}+0.007 \mathrm{C}_{4} \mathrm{H}_{6} \mathrm{O}_{6}$

$2-0.05 \mathrm{SbOCl}+0.05 \mathrm{H}_{2} \mathrm{SeO}_{3}+0.007 \mathrm{C}_{4} \mathrm{H}_{6} \mathrm{O}_{6}$

3- $0.05 \mathrm{H}_{2} \mathrm{SeO}_{3}+0.007 \mathrm{C}_{4} \mathrm{H}_{6} \mathrm{O}_{6}$

$\mathrm{T}=298 \mathrm{~K}, \mathrm{E}_{\mathrm{V}}=0.02 \mathrm{~V} / \mathrm{s}$.

Moreover, the qualities of electrodeposited films are also changed. At 298-318 K temperature intervals a black, uniform, crystalline, shiny coating of $\mathrm{Sb}_{2} \mathrm{Se}_{3}$ compound is formed. But at high temperatures, the black, uneven, loose films are formed on the cathode with a weak clutch on the surface of the electrode. Therefore, all next experiments to obtain thin films of $\mathrm{Sb}_{2} \mathrm{Se}_{3}$ compound were accomplished at $298 \mathrm{~K}$ temperature. 


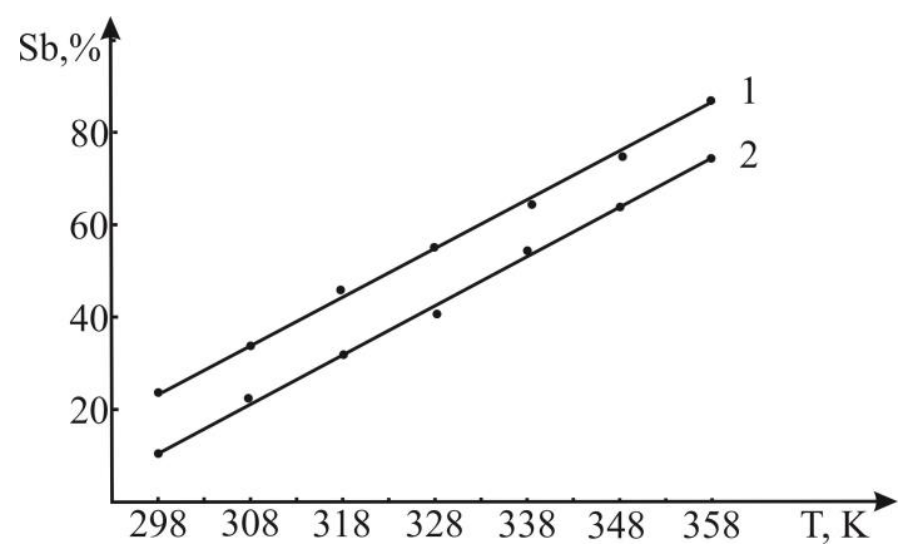

Fig. 2. The dependence between stibium content in the electrodeposited thin films and temperature. Electrolyte (M): $0.05 \mathrm{SbOCl}+0.05 \mathrm{H}_{2} \mathrm{SeO}_{3}+$ $0.007 \quad \mathrm{C}_{4} \mathrm{H}_{6} \mathrm{O}_{6}$. The current density $\left(\mathrm{mA} / \mathrm{sm}^{2}\right)$ : 1- 30:

Moreover, the concentration of the initial components effects on the composition of the electrodeposited thin films.

In Fig. 3, the effect of concentration of basic component $\mathrm{SbOCl}$ on deposited composition is shown. As follows from Fig. 3, the effect of $\mathrm{SbOCl}$ concentration was studied

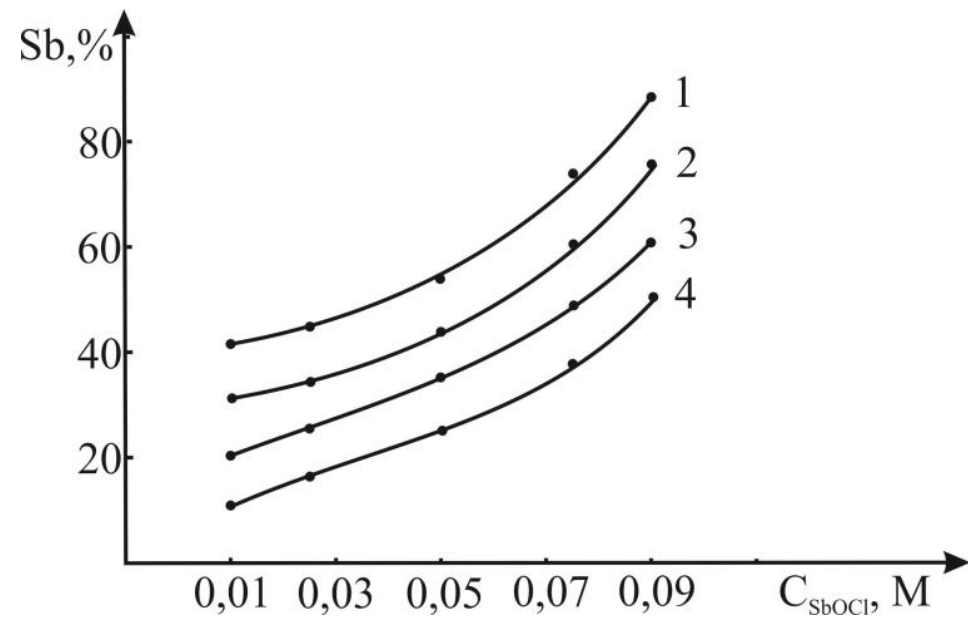

within 0.01-0.09 $\mathrm{M}$ intervals, and its increase in electrolyte affects compositions and qualities of the obtained deposits. Despite this, the rise in the current density reduces the stibium content in the composition of thin films.
Fig. 3. The dependence between stibium content in the electrodeposited thin films and concentration of $\mathrm{SbOCl}$ in electrolyte. Electrolyte (M): $0.05 \quad \mathrm{H}_{2} \mathrm{SeO}_{3}+0.007$ $\mathrm{C}_{4} \mathrm{H}_{6} \mathrm{O}_{6}$. The current density $\left(\mathrm{mA} / \mathrm{sm}^{2}\right)$ : $1-$ 20; 2- 30; 3- 40; 4- 60. T=298K.
The effect of current density on the stibium content in the obtained films was studied within $20-60 \mathrm{~mA} / \mathrm{sm}^{2}$ intervals. Note that the experiments were carried out with various concentrations of the initial components. According to Fig. 4, the increase of current density during the electrodeposition of $\mathrm{Sb}-\mathrm{Se}$ has an effect on compositions and qualities of the obtained thin films. The results indicate that the thin films closer to stoichiometric composition were formed from an electrolyte with contents of $0.05 \mathrm{MSbOCl}+$ $0.05 \mathrm{M} \mathrm{H}_{2} \mathrm{SeO}_{3}+0.007 \mathrm{M} \mathrm{C}_{4} \mathrm{H}_{6} \mathrm{O}_{6}$ and at $20-30$ $\mathrm{mA} / \mathrm{sm}^{2}$ current density. Thus, the stibium and selenium contents in the deposits are $51.4 \%$ and $48.6 \%$ respectively. However, as the current density increases up to $60 \mathrm{~mA} / \mathrm{sm}^{2}$, the stibium content in the deposits decreases sharply down to $18.8 \%$. 


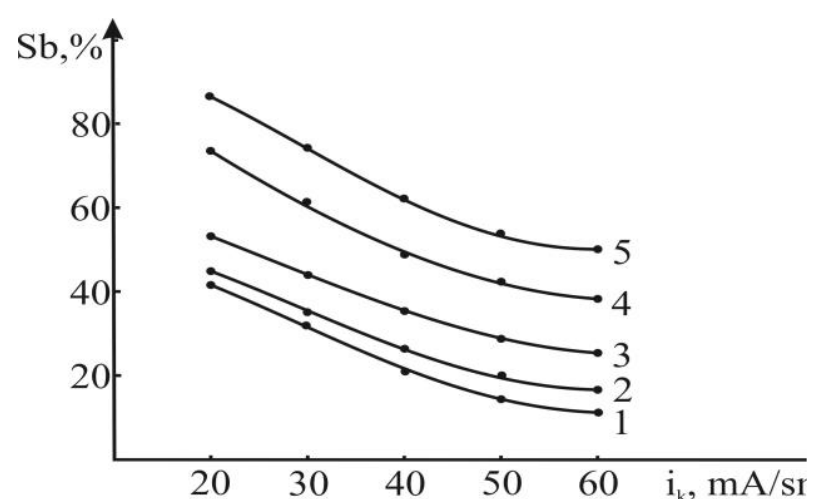

Changes in the concentration of $\mathrm{H}_{2} \mathrm{SeO}_{3}$ in the electrolyte also notably affect on the composition of the electrodeposited thin film.

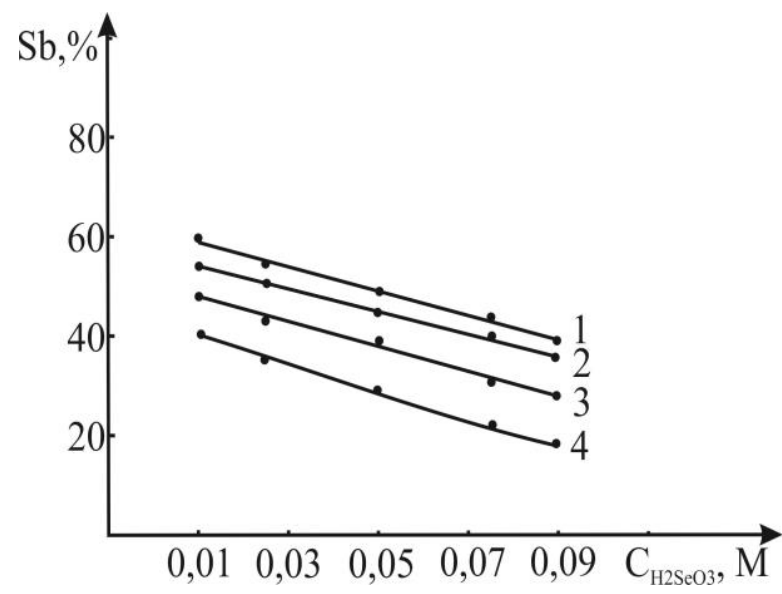

Investigation of the effect of this factor shows that as $\mathrm{H}_{2} \mathrm{SeO}_{3}$ concentration in the electrolyte rises, the stibium content in the films decreases. Thus, at $20-60 \mathrm{~mA} / \mathrm{sm}^{2}$

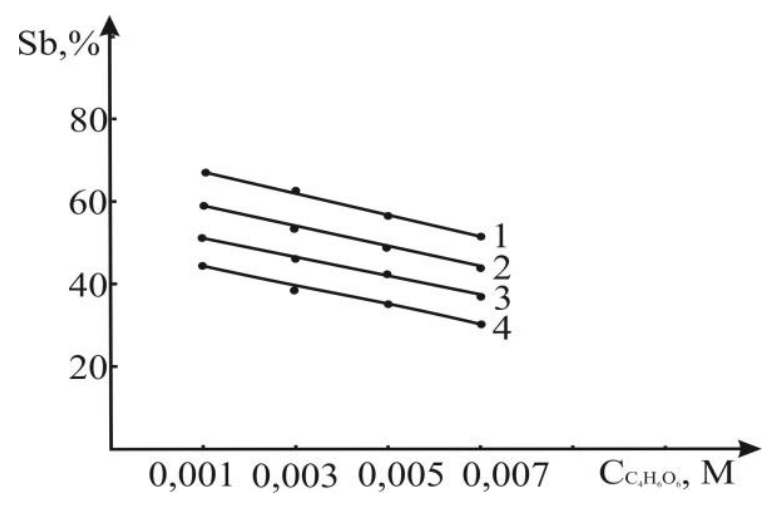

According to Fig. 6, as the concentration of tartaric acid in the electrolyte rises from 0.001 to $0.007 \mathrm{M}$, the stibium content in
Fig. 4. The dependence between the stibium content in the electrodeposited thin films and current density. $\mathrm{T}=298 \mathrm{~K}$, Electrolyte $(\mathrm{M})$ :

1. $0.01 \mathrm{SbOCl}+0.05 \mathrm{H}_{2} \mathrm{SeO}_{3}+0.007 \mathrm{C}_{4} \mathrm{H}_{6} \mathrm{O}_{6}$

2. $0.25 \mathrm{SbOCl}+0.05 \mathrm{H}_{2} \mathrm{SeO}_{3}+0.007 \mathrm{C}_{4} \mathrm{H}_{6} \mathrm{O}_{6}$

3. $0.5 \mathrm{SbOCl}+0.05 \mathrm{H}_{2} \mathrm{SeO}_{3}+0.007 \mathrm{C}_{4} \mathrm{H}_{6} \mathrm{O}_{6}$

4. $0.75 \mathrm{SbOCl}+0.05 \mathrm{H}_{2} \mathrm{SeO}_{3}+0.007 \mathrm{C}_{4} \mathrm{H}_{6} \mathrm{O}_{6}$

5. $0.09 \mathrm{SbOCl}+0.05 \mathrm{H}_{2} \mathrm{SeO}_{3}+0.007 \mathrm{C}_{4} \mathrm{H}_{6} \mathrm{O}_{6}$

The dependence of the influence of this factor is shown in Fig. 5.

Fig. 5. The dependence between stibium content in the electrodeposited thin films and the concentration of $\mathrm{H}_{2} \mathrm{SeO}_{3}$ in electrolyte. Electrolyte (M): $0.05 \mathrm{SbOCl}+0.007$ $\mathrm{C}_{4} \mathrm{H}_{6} \mathrm{O}_{6}$. The current density $\left(\mathrm{mA} / \mathrm{sm}^{2}\right): 1$ 20; 2 - 30; 3 - 40; 4 - 60. T=298K.

current density in terms c $\mathrm{H}_{2} \mathrm{SeO}_{3}$ concentration rise in electrolyte from 0.01 to $0.09 \mathrm{M}$, the stibium content in the deposits decreases from 60.7 to $19.2 \%$.

Fig. 6. The dependence between the stibium content in the electrodeposited thin films and the concentration of $\mathrm{C}_{4} \mathrm{H}_{6} \mathrm{O}_{6}$ in electrolyte. Electrolyte (M): $0.05 \mathrm{SbOCl}+0.05 \mathrm{H}_{2} \mathrm{SeO}_{3}$. The current density $\left(\mathrm{MA} / \mathrm{cm}^{2}\right): 1$ - 20; 2 - 30; 3 - 40; 4 - 60. $\mathrm{T}=298 \mathrm{~K}$.

electrodeposited thin films decreases depending on current density from 67.2 to $30.1 \%$. 


\section{CONCLUSIONS}

The simultaneous deposition process of stibium with selenium on the Pt electrodes from tartaric electrolytes has been studied by electrochemical method.

The effect of concentrations of the initial components, temperature and current density on electrodeposition process of the SbSe thin films was also investigated. The results of all experiments indicate that the increase in the temperature and concentration of $\mathrm{SbOCl}$ leads to the rise in the stibium content of the films. Also, when the current density, $\mathrm{H}_{2} \mathrm{SeO}_{3}$ and $\mathrm{C}_{4} \mathrm{H}_{6} \mathrm{O}_{6}$ concentrations increase the stibium content in the obtained films decreases respectively. The optimal condition and electrolyte composition for electrodeposition process of Sb-Se compound were chosen due to the use of these results. Uniform, crystalline, shiny coatings of $\mathrm{Sb}_{2} \mathrm{Se}_{3}$ are reproduced within temperature intervals $298-318 \mathrm{~K}$, current density at 20-60 $\mathrm{MA} / \mathrm{cm}^{2}$ from electrolyte of $0.01-0.09 \mathrm{M}$ SbOCl, 0.01-0.09 $\mathrm{M} \mathrm{H}_{2} \mathrm{SeO}_{3}$ and 0.001- 0.007 M compounds of tartaric acid.

\section{REFERENCES}

1. Patil P.B., Mali S.S., Kondalkar V.V. et al. Morphologically controlled electrodeposition of fern shaped $\mathrm{Bi}_{2} \mathrm{Te}_{3}$ thin films for photoelectrochemical performance. Journal of Electroanalytical Chemistry, 2015, vol. 758, pp. 178-190.

2. Aliyev A.S., Elrouby M., Cafarova S.F. Electrochemical synthesis of molybdenum sulfide semiconductor. Materials Science in Semiconductor Processing, 2015, vol. 32, p. 31-39.

3. Huseynov G.M., Mammadova N.A., Imanov H.A. Obtaining of nanosized compound $\mathrm{Sb}_{2} \mathrm{~S}_{3}$ on the basis of tioacetamide and antimony (III) chloride. Kimya Problemleri - Chemical Problems. 2017, no. 3, pp. 329-334 (İn Azerbaijan).

4. Ali Eftekhar. Molybdenum diselenide $\left(\mathrm{MoSe}_{2}\right)$ for energy storage, catalysis, and optoelectronics. Applied Materials Today, 2017, vol. 8, pp. 1-17.

5. Aliyev A.Sh., Eminov Sh.O., Sultanova T.Sh. et al.Electrochemical production of thin films of cadmium sulphide on nickel electrodes and research into their morphology. Kimya Problemleri Chemical Problems, 2016, no. 2, pp. 139145. (İn Azerbaijan)

6. Kulova T.L., Nikolaev I.I., Fateev V.N.,
Aliyev A.Sh. Modern electrochemical sistems of energy accumulation. Kimya Problemleri - Chemical Problems. 2018, no. 1, pp. 9-34. (İn Azerbaijan)

7. Solar energy conversion. Solid-State Physics Aspects. Edited by B.O.Seraphin, Springer-Verlag, Berlin, Heidelberg, New York, 1979, $320 \mathrm{p}$.

8. Dunyushkina L.A. Introduction to methods of obtaining electrolytes for solidoxide fuel cells. Yekaterinburg: URORAN Publ. 2015, $126 \mathrm{p}$.

9. Virt I.S., Rudiy I.A., Kurilo I.V. et al. The properties of $\mathrm{Sb}_{2} \mathrm{~S}_{3}$ and $\mathrm{Sb}_{2} \mathrm{Se}_{3}$ thin films obtained by pulsed laser ablation. Physics and equipment of semiconductors, 2013, vol. 47, no. 7, pp. 997-1001.

10. Majidzade V.A., Guliyev P.H., Aliyev A.S. et al. Electrochemical characterization and electrode kinetics for antimony electrodeposition from its oxychloride solution in the presence of tartaric acid. $J$. Mol. Struct. 2017, vol. 1136, pp. 7-13.

11. Majidzade V.A., Aliyev A.Sh., Guliyev P.H. et al. Electrochemical behavior of selenite ions in tartaric electrolytes. $J$. Electrochem. Sci. Eng. 2018, vol. 8, no. 3. pp. 195-202; doi:10.5599/jese.4901. 


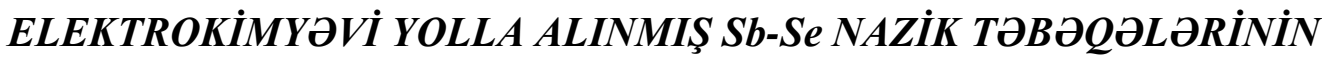 TORKIBINO MÜXTOLIF AMILLORIN TOSIRI
}

\author{
V.A. Mocidzado
}

AMEA-nın akad. M.Nă̆ıyev adına Kataliz vo Qeyri-üzvi Kimya İnstitutu AZ 1143, Bakı, H.Cavid pr., 113; e-mail:vuska_80@mail.ru

Taqdim edilan iş elektrokimyəvi üsulla çökdürülmüş Sb-Se nazik təbəqalarinin tarkibinə müxtəlif amillarin - temperaturun, elektrolitdo komponentlarin qatılığının, carayan sıxlı̆̆ının təsirinin tadqiqina hasr edilmişdir. Naticalar göstarir ki, temperaturun va SbOCl-in qatılığının artmast ila çökən nümunəlardə sürmənin miqdarı artır. Digər faktorların təsiri zamanı isə alınan nümunələrdə sürmənin miqdarı azalır. Müəyyən edilmişdir ki, Sb ${ }_{2} \mathrm{Se}_{3}$ kimyəvi birləşməsinin qara rangli, eyni qalınlıqda, kristallik, parlltılı örtüklari 298-318 K temperaturda, 20-60 mA/sm ${ }^{2}$ carayan slxlı̆̆ında, 0.01-0.09M SbOCl, 0.01-0.09M $\mathrm{H}_{2} \mathrm{SeO}_{3}$ vo 0.001-0.007 M çaxır turşusu tarkibli elektrolitdon alınır.

Açar sözlori: elektroçökmə, Sb-Se nazik tabaqalari, cərəyan sıxlı̆̆l, yarımkeçiricilar

\section{ВЛИЯНИЕ РАЗЛИЧНЫХ ФАКТОРОВ НА СОСТАВ ЭЛЕКТРОЛИТИЧЕСКИХ ТОНКИХ ПЛЕНОК $\mathrm{Sb}$-Se}

\author{
В.А. Меджидзаде \\ Институт катализа и неорганической химии им. акад. М.Нагиева \\ Национальной АН Азербайджана \\ AZ 1143 Баку, пр.Г.Джавида, 113; e-mail: vuska_80@mail.ru
}

\begin{abstract}
В работе изучено влияние различных факторов - температуры, концентрации компонентов в электролите, плотности тока на состав электроосажденных тонких полупроводниковых пленок Sb-Se. Результаты показывают, что $c$ повышением температуры и концентращии $\mathrm{SbOCl}$ содержание сурьмы в осадках увеличивается. А при увеличении плотности тока, концентрачии $\mathrm{H}_{2} \mathrm{SeO}_{3}$ и $\mathrm{C}_{4} \mathrm{H}_{6} \mathrm{O}_{6}$ содержание сурьмь в полученных пленках соответственно уменьшается. Установлено, что чернье, равномерные, кристаллические, блестящие покрытия соединения $\mathrm{Sb}_{2} \mathrm{Se}_{3}$ получаются в

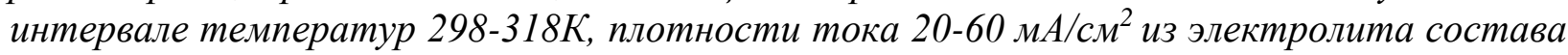
0.01-0.09 M SbOCl, 0.01-0.09 $\mathrm{M} \mathrm{H}_{2} \mathrm{SeO}_{3}$ и 0.001-0.007 М винной кислоты.
\end{abstract}

Ключевые слова: электроосаждение, тонкие пленки $\mathrm{Sb}-\mathrm{Se}$, плотность тока, полупроводники 